Journal of Primary Education
$9(3)(2020): 303-310$
UNNES
https://journal.unnes.ac.id/sju/index.php/jpe

\title{
Analysis of Mathematical Literacy Skills through PMRI Approaches of Elementary School Students
}

\author{
Trinil Wigati $^{1 凶}$, Wardono Wardono ${ }^{2}$, Eko Purwanti $^{2}$ \\ DOI: https://doi.org/10.15294/jpe.v9i3.39212 \\ ${ }^{1}$ SD Negeri Panggung Lor Semarang, Indonesia \\ ${ }^{2}$ Pascasarjana, Universitas Negeri Semarang, Indonesia
}

\begin{abstract}
Article Info
Abstract

History Articles

Students' low mathematics literacy skills are due to the lack of students' skills Received: to solve mathematical problems related to the real world. The objective of this 27 February 2020

Accepted:

28 March 2020

Published:

31 May 2020

Keywords:

Analysis,

Mathematical

Literacy, PMRI. study is to analyse the improvement of mathematics literacy skills of fifth-grade elementary school students and describe the mathematical literacy skills of elementary students through the PMRI approach. The method used was a mixed method with concurrent embedded design to analyse quantitative data on the quality of the PMRI approach and qualitative data to analyse the mathematical literacy skills of fifth-grade elementary school students. The results show that by using the PMRI approach, classical mastery learning can be achieved and the average students' mathematical literacy skills are higher than the expository model. It is shown from the classical completeness results $z_{\text {count }}>Z_{(0,5-\alpha)}$, it is $2.065>0.4678$. Therefore, the proportion of students who learn through the PMRI approach reaches more than $75 \%$. While the data analysis of mathematics literacy skills of fifth-grade elementary school students has good ability in expressing mathematical ideas, turning problems into mathematical models, using strategies, symbols and tools correctly, and can make conclusions.
\end{abstract}

\footnotetext{
$\triangle$ Correspondence address:

Puspowarno Street IV/ 22 ASemarang, Jawa Tengah Indonesia

E-mail: trinilwigati@gmail.com

p-ISSN 2252-6404

e-ISSN 2502-4515
} 


\section{INTRODUCTION}

According to the Regulation of Indonesian Minister of National Education No. 22 of 2016 concerning Basic and Secondary Education Process Standards, the learning process in the education unit is carried out interactively, inspiring, fun, challenging, motivating students to participate actively, as well as providing sufficient space for the initiative, creativity, and independence according to talent, interests, and physical and psychological development of students. One of the subjects in the 2013 curriculum that has this characteristic is Mathematics. The functions of Mathematics in schools are to provide basic skills in Mathematics and to form a logical, critical, careful, creative thinking skills and disciplined attitude. Therefore, the teacher must be able to apply quality and appropriate teaching methods, which ultimately students feel motivated to study harder.

Mathematics literacy is needed by all people in dealing with problems in modern life, because mathematical literacy is very closely related to work and tasks in daily life (Wong, 2011 \& Stacey, 2012a). Unfortunately, students' mathematical literacy skills are still very low. According to Johar (2012), knowledge and understanding of concepts in mathematics are very important, without neglecting the ability to activate mathematical literacy to solve problems encountered in everyday life. Therefore, it is important to do hard effort to improve the students' mathematical literacy.

The cognitive development of elementary school-age children according to Piaget enters a concrete operational stage (Bakir \& Bİçer, 2015). At this age, it can be said that they can "think" (Egan, 2012). Thus, elementary school-age children are able to understand concrete concepts. It means that learning tools starting from teaching materials, materials, or the media must provide real pictures to students. Furthermore, in mathematics, learning should refer to the cognitive development theory of Piaget, where elementary school-age students are entering a concrete operational stage (Egan,
2012). This is in line with one of the competencies of mathematics in elementary schools; it is using concrete and symbolic models or other strategies in solving everyday problems (Ministry of Education and Culture, 2016). Ideally, learning mathematics in elementary schools is realistic. Also in practice of mathematics learning, children are associated with everyday problems into the world of mathematics so that students' mathematical experiences can be developed.

One approach of learning mathematics that is relevant to the theory of cognitive development of elementary school-age children is realistic mathematics education (RME) or Indonesian Realistic Mathematics Education (PMRI). The RME is a mathematics learning approach based on combining mathematics with the real world (Sumirattana, Makanong, \& Thipkong, 2017). By combining mathematics learning with real life, it will increasingly make learning activities meaningful (Herawati, 2016).

The definition of mathematical literacy as quoted in the PISA report 2012 (in Mahdiansyah \& Rahmawati, 2014) is the skill of individuals to formulate, apply, and interpret mathematics in various contexts. This skill includes mathematical reasoning; skill to use mathematical concepts, procedures, and facts; as well as mathematical functions to describe, explain, and predict a phenomenon. There are seven components of skill contained in mathematical literacy. They are (1) communication, (2) mathematical (3) restatement, (4) reasoning and giving reasons, (5) using problem-solving strategies, (6) using symbols, formal language and techniques, and (7) using mathematical tools.

According to Kusuma, Wardono, \& Winarti (2016), RME is a mathematical learning approach that uses contextual problems as a first step in the learning process. Through the PMRI approach, the problem used is contextual issues.

According to Asikin \& Junaedi (2013), the results of research in the Netherlands show that RME has shown satisfactory results (Becker \& Selter, 1996). In Indonesia, RME is often referred to as Indonesian Realistic Mathematics 
Education (PMRI). PMRI has been applied in education in Indonesia because it makes it easy for students to solve problems because they relate to everyday life (Budiono \& Wardono, 2014). According to Rohman (2013), PMRI learning is one of the lessons under the guidance of the teacher based on the concept of Freudenthal; mathematics must be connected with reality; be close to students' relevant to people's lives; and must be transmitted as human activities. This is an advantage of PMRI as stated by Wardono (2014) the advantage of PMRI is to emphasize learning by doing, in accordance with the concept developed by Freudental, that is by linking matters related to real life. A factor that might influence the improvement of student capabilities in mathematics literacy is the application of approaches in mathematics learning.

Based on these problems mentioned, this study was conducted to analyze the quality of learning through the PMRI approach in improving the mathematics literacy skills of elementary school students and describing the mathematics literacy skills of elementary students.

\section{METHODS}

The research method used was a mixed method with concurrent embedded design. Concurrent embedded research had primary methods that guide research and secondary methods as supporting roles (Sarwi \& Rusilowati, 2013). In this study, quantitative research was used as the primary method and qualitative research as a secondary method.

Quantitative data were collected to study the quality of learning by using the PMRI approach. The quality of learning is describing by triangulating data from Mathematics Literacy
Skills Tests, observation, questionnaires, documentation, and interviews. Quantitative data analysis included validity test, reliability test, discriminance power test, normality test, homogeneity test, and final data analysis included classical completeness test (proportion), t-test and n-gain test were conducted respectively to determine classical completeness, average difference, and improvement of average pre-test and post-test scores. The qualitative data were collected form interviews to analyze the mathematical literacy skills of elementary school students.

The subjects of this study were 65 students at Panggung Kidul 01 State Elementary School and Panggung Kidul 02 State Elementary School. There were 32 students as the control class and 33 students as the experimental class.

\section{RESULTS AND DISCUSSION}

The results of the average pre-test of Mathematics Literacy Skills Tests for control and experimental classes are still low with Minimum Mastery Criteria, with score 65, as shown in Table 1.

Table 1. Average pre-test score of Mathematics Literacy Skills Tests

\begin{tabular}{cc}
\hline Class & Average \\
\hline Control & 57.13 \\
Experiment & 63.21
\end{tabular}

Before the experimental class is treated with learning the PMRI approach, the normality test is done first because the use of inferential parametric statistics requires that the data to be analyzed must be normally distributed. The results of the pretest and posttest normality tests are presented in Table 2. 
Tabel 2. Pretest and Posttest Normality

\begin{tabular}{lllll}
\hline & \multicolumn{2}{c}{ Pretest } & \multicolumn{2}{c}{ Postest } \\
& Control & Experiment & Control & Experiment \\
\hline Normal & 32 & 33 & 32 & 33 \\
Mean & 57.13 & 63.21 & 68.88 & 77.81 \\
Std Deviation & 14.53 & 16.17 & 7.8 & 9.88 \\
Kolmogorov- Smirnov Z & 0.471 & 0.721 & 0.813 & 0.804 \\
Asym.Sig.(2-Tailed) & 0.980 & 0.676 & 0.522 & 0.538 \\
\hline
\end{tabular}

The hypothesis for the normality test is if the initial capability data of $\mathrm{HO}$ is normally distributed and if the initial capability data of $\mathrm{H} 1$ is not normally distributed. Test criteria if the significance value $>0.05(\alpha)$ then $\mathrm{HO}$ is accepted. From Table 2 it can be seen that all data are normally distributed.

A homogeneity test is conducted to find out whether the control and experimental class have the same ability (homogeneous) or not. The test criterion is that the data is said to be homogeneous if the value of Fcount (Flevene statistic) $<$ Ftabel and the significance value is higher than $\sigma$ with $\sigma=0.05$. Homogeneity test results can be seen in Table 3 .

Table 3. Homogeneity Test Results of Pre-test and post-test scores.

\begin{tabular}{lllll}
\hline & $\begin{array}{l}\text { Lavene } \\
\text { Statistic }\end{array}$ & df1 & df2 & sig \\
\hline Pre-test & 0.134 & 1 & 63 & 0.716 \\
Post- & 0.797 & 1 & 63 & 0.375 \\
test & & & & \\
\hline
\end{tabular}

In Table 3, it is known that based on the Test of Homogeneity of Variances table, the significance value of pretest is 0.716 and the posttest significance is 0.375 . Because $0.716>$ 0.05 and $0.375>0.05$. It can be concluded that pretest and posttest data of the control and experiment have the same variance (homogeneous).

Classical completeness test (proportion) is used to determine the success of students who are taught by using the PMRI approach. The results are compared with ztable values with a significant level of $5 \%$. If $z_{\text {count }}>z_{(0,5-\alpha)}$ then $\mathrm{HO}$ is rejected. It is obtained that $\mathrm{z}$ count value of $2.065>0.4678$. So, the proportion of students who completed Minimum Mastery Criteria after the learning process with the PMRI approach was more than $75 \%$.

Furthermore, the t-test is used to test the mathematical literacy skills of students in the experimental class and the control class by comparing the average score of the results of the mathematics literacy skills test. The test criterion is that H0 is accepted if $\mathrm{t}_{\text {count }}<t_{(1-\alpha)}$ $\left(n_{1}+n_{2}-2\right)$. Value of $t$ table can be obtained from the $\mathrm{t}$ distribution list with $d f=32+33-2=$ 63 for the probability $(1-\propto)$ and the significance level $=0.05$. The results obtained $t_{\text {table }}=1.669$. Because $24.615>1.669$ then $H_{0}$ is rejected. This means that the average mathematical literacy skills of students in the learning process by using the PMRI approach are higher than the average mathematical literacy skills of students in expository learning.

The purpose of the improvement test is to know how much the improvement in the average of students' mathematical literacy skills of the experimental class compared to the control class by using the Normilized-Gain (Ngain, $<\mathrm{g}>$ ) formula. $\mathrm{N}$-gain test is the difference between the post-test and pre-test scores, the $\mathrm{N}$ gain shows an improvement in understanding or mastery of students' mathematical literacy after the teacher's learning. The results of the $\mathrm{N}$-gain test is presented in Table 4 and Table 5 . 
Table 4. N-gain grouping results

\begin{tabular}{lllll}
\hline \multirow{2}{*}{ Criteria } & \multicolumn{2}{c}{ N-gain } & \multicolumn{2}{c}{ Percentage } \\
& Control & Experiment & Control (\%) & Experiment (\%) \\
\hline Low & 14 & 10 & 43.75 & 30.30 \\
Medium & 18 & 19 & 56.25 & 57.58 \\
High & 0 & 4 & 0 & 12.12 \\
\hline
\end{tabular}

Table 5. N-gain Score Average

\begin{tabular}{ll}
\hline Class & $\mathrm{N}-$ Gain Average \\
\hline Control & 0.20 \\
Experiment & 0.38 \\
\hline
\end{tabular}

Based on Table 4 and Table 5, the difference in the improvement can be seen from the calculation results that the experimental class is higher than the control class. Hence, it can be concluded that learning with the PMRI approach has improved more significantly compared to expository learning. This is in line with the results of research conducted by Wardono (2014), Widyastuti (2014), Rahmah Johar (2016), Peni (2017), and Wardono \& Mariani (2018).

The analysis of the profile of students' mathematical literacy skills is divided into three categories, they are high group mathematics literacy skills, medium group mathematics literacy skills, and low group mathematics literacy skills. The research subjects were chosen by six students from each level of mathematical literacy skills so that selected SP1, SP2 (high group), SP3, SP4 (medium group), SP5, SP6 (low group).

Figure 1 is an example of the results of the subject's work in the high group category. At the 1st meeting, the students are still cannot reinterpret mathematical results into real problems. The students

also cannot express the exact reasons of mathematical solutions into real problems.

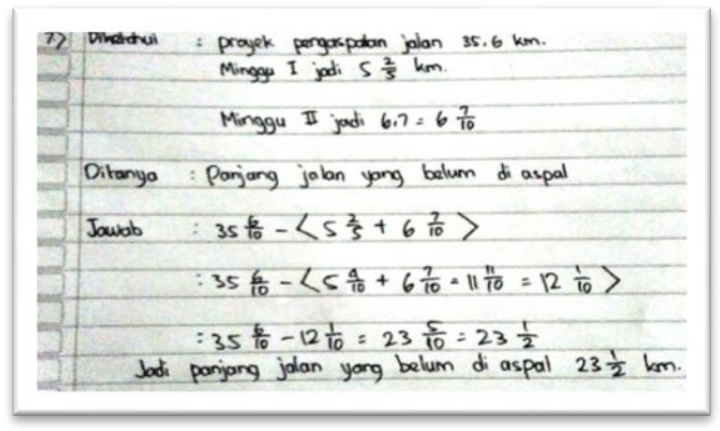

Figure 1. Answers to Mathematics Literacy Ability Tests (SP-01)

Figure 2 is the result of the work of the high group subject.

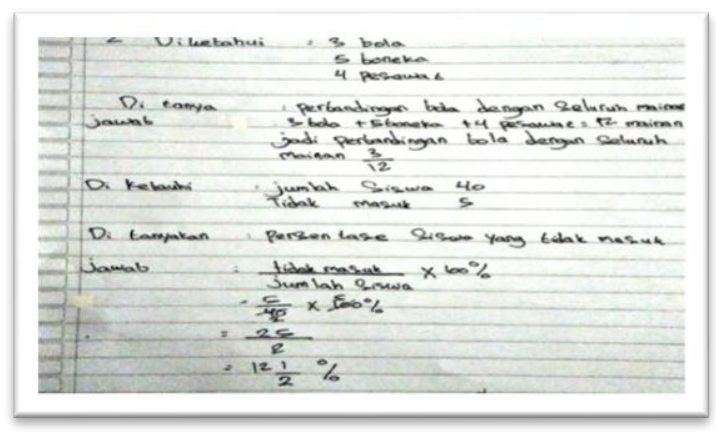

Figure 2. Answers to Mathematics Literacy Ability Tests (SP-02)

However, when the teaching-learning process, SP-01 and SP-02 seems enthusiastic in carrying out activities according to hand-on activity. From the pre-test results of the first to fourth meetings until the post-test, SP-01 and SP-02 seems to have a significant improvement. The subject can turn problems into mathematical models, design, and implement strategies to find mathematical solutions.

For medium group subjects (SP-03 and SP-04), at the beginning of the meeting, they have difficulty in formulating the problem situation mathematically, they cannot write 
down what is known and asked of the problem, the part is very important so that they can plan and then implement the strategy to find solutions to problems. Figure 3 is the result of the work of the medium group subject.

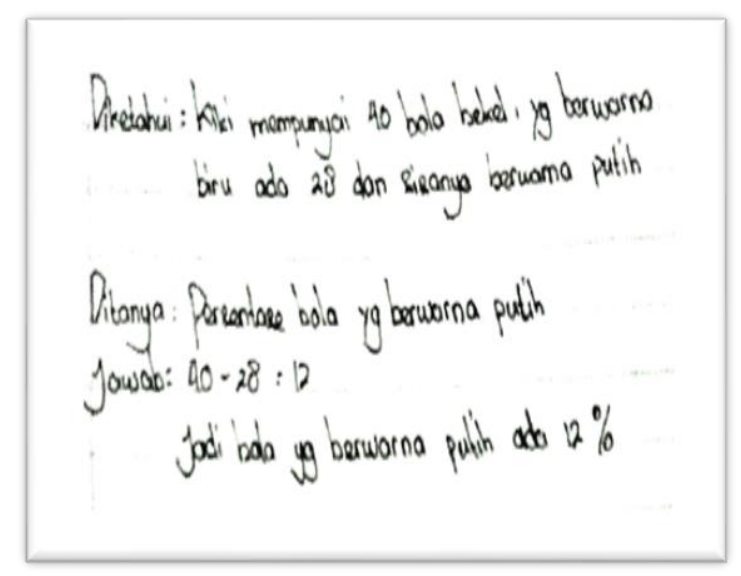

Figure 3. Answers to Mathematics Literacy Ability Tests (SP-03)

At the 1st meeting, the students are still cannot reinterpret mathematical results into real problems, they also cannot express the exact reasons of mathematical solutions into real problems. Figure 4 is an example of the results of the work of medium group subject categories

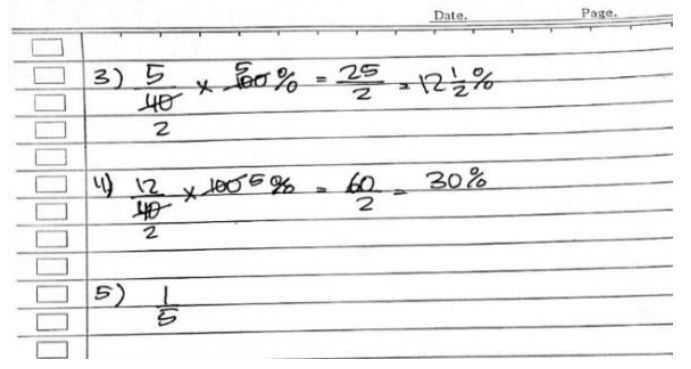

Figure 4. Answers to Mathematics Literacy Ability Tests (SP-04)

However, students practice a lot of literacy problems so that there is an improvement compared to before. Furthermore, for low groups (SP-05 and SP-06). At the beginning of the meeting, students had difficulty in understanding the problems so they are not accustomed to formulating mathematical situations and identifying the problem variables that exist in real context situations. Students have difficulty turning problems into mathematical models and interpreting results into original problems, so students have difficulty finding the final results. Figure 5 is an example of the results of the work of low group subject categories.

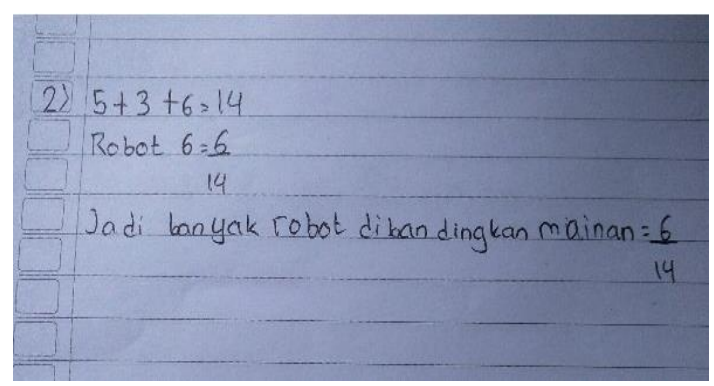

Figure 5. Answers to Mathematics Literacy Ability Tests (SP-05)

At the 1st meeting, students cannot reinterpret mathematical results into real problems. Students also cannot express the exact reasons of mathematical solutions into real problems. Figure 6 is an example of the results of the work of low group subject categories.

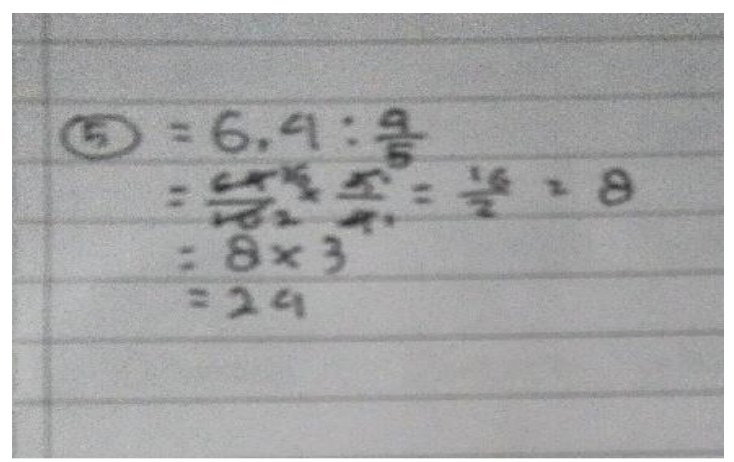

Figure 6. Answers to Mathematics Literacy Ability Tests (SP-06)

However, as the meeting progressed, the more significant improvements are seen and they include medium criteria. At the end of the meeting, students reinterpret mathematical results into real problems even though there are still errors.

High group students, SP1, SP2, and medium groups, SP3, SP4, have high skills in communicating problems, turning real problems into mathematics, presenting problems into pictures correctly, can write plans for solving problems in order, whereas in low groups, SP5, SP6, have difficulty in planning the problemsolving in advance in the aspects of 
mathematizing, representation, and reasoning and argument.

High groups (SP1, SP2) require a long duration of time in solving problems, but the answers given tend to be correct. Medium groups (SP2, SP3) take a long time to solve problems but tend to make a few mistakes in working on problems. Low groups (SP5, SP6) require a long time, make a lot of mistakes in working on problems, and there is sufficient improvement in their skills. Based on differences in the mathematical literacy skills of each group, it can be concluded that high and medium group students have a better chance of improving mathematical literacy skills than low group students.

\section{CONCLUSION}

This research concludes that learning mathematics in fractions material by using the PMRI approach can improve the mathematics literacy of fifth-grade elementary school students. High groups require a long time in solving problems, but the answers given tend to be correct. The medium group takes a long time to solve the problem but tends to make some mistakes in working on the problem. Low groups require a long time but make a lot of mistakes in working on problems, and there is sufficient improvement in their skills.

\section{ACKNOWLEDGMENT}

I would like to express my gratitude to Universitas Negeri Semarang, Panggung Lor State Elementary School, and Panggung Kidul State Elementary School as research institutions for giving me opportunity to conduct my research

\section{REFERENCES}

Asikin, M. \& Junaedi, I. (2013). Kemampuan Komunikasi Matematika Siswa SMP dalam Setting Pembelajaran RME (Realistic Mathematics Education). Unnes
Journal of Mathematics Education Research, 2(1):204-213.

Bakir, S., \& Bİçer, E. Ö. (2015). Logical Thinking and Cognitive Development Levels of Pre-service Science Teachers. Journal of Educational Sciences Research, 5(1), 149-163.

Herawati, F. (2016). Pengembangan Perangkat Pembelajaran Matematika dengan Pendekatan PMRI Berorientasi Pada Kemampuan Representasi

Matematis. Jurnal Riset Pendidikan Matematika, 31(3): 34-44.

Johar, R. (2012) "Domain Soal PISA untuk Matematika". Makalah. Seminar dan lokakarya dalam rangka kontes literasi matematika (KLM) Universitas Negeri Semarang 29 September 2012.

Johar, R., Zubaidah, T., \& Mariana, N. (2016). Upaya Guru Mengembangkan Karakter Siswa Melalui Pembelajaran Matematika Dengan Pendekatan Realistic Pada Materi Perkalian. Jurnal Pendidikan Matematika Sriwijaya. 10 (1): 96-113

Kemdikbud. (2016). Peraturan Menteri Pendidikan dan Kebudayaan Republik Indonesia Nomor 22.Tahun 2016 Tentang Standar Proses Pendidikan Dasar dan Menengah. Climate Change 2013 - The Physical Science Basis, 1-30.

Kusuma, B. J., Wardono, \& Winarti, E. R. 2016. Kemampuan Literasi Matematika Siswa Kelas VIII pada Pembelajaran Realistik Berbantuan Edmodo. Unnes Journal of Mathematics Education Research, 5(3) : 200-206.

Mansyahdiah dan Rahmawati (2014) Literasi Matematika Siswa Pendidikan Menengah : Analisis Menggunakan Desain Tes Internasional dengan Konteks Indonesia Jurnal Pendidikan dan Kebudayaan, 20(4): 452-469

Nur Sri Widyastuti, P. Pujiastuti (2014) The Effects Of Realistic Mathematics Education Indonesia (PMRI) On Understanding Concepts And Logical Thinking Students, Jurnal Prima Edukasia, 2 (2): $183-193$ 
Ojose, B.(2011) "Mathematics Literacy. Are We Able to Put The Mathematics We Learn Into Everyday User?". Journal of Mathematics Educations, 4(1): 89 - 100

Peni, N.R.N. (2017). Pengaruh Permainan Jakri Terhadap Pemahaman dan Minat Siswa Sekolah Dasar dalam Menyelesaikan Soal Cerita: Kasus dengan Pendekatan Realistic Mathematics Education. Unnes Journal of Mathematics Education, 6(2): 268276.

Riyanto, R., Wardono, W. \& Wijayanti, K., (2014) Keefektivan PMRI Berbantuan Alat Peraga Terhadap Kemampuan Pemecahan Masalah Serupa PISA Pada Kelas VII. Kreano, Jurnal Matematika Kreatif-Inovatif, 5(1):33-40.

Sari, R.H.N. (2015) Literasi Matematika: Apa, Mengapa dan Bagaimana? Prosding. Seminar Nasional Matematika dan Pendidikan Matematika UNY 2015

Stacey, Kaye. (2010). The PISA view of Mathematical Literacy in Indonesia. Journal On Mathematics Education (IndoMSJME) 2(2) : 95-126

Stacey, K. (2011) The View of Mathematical Literacy in Indonesia. Journal on Mathematics Education (IndoMS-JME), 4(2): 1-24.

Sugiman \& Kusuma, Y.S. (2010). Dampak pendidikan matematika realistic terhadap peningkatan kemampuan pemecahan masalah siswa SMP. IndoMS Journal Mathematics Educations, 1, 41-51
Sumirattana, S., Makanong, A., \& Thipkong, S. (2017). Using realistic mathematics education and the DAPIC problemsolving process to enhance secondary school students' mathematical literacy. Kasetsart Journal of Social Sciences, 38(3): 307-315.

Wardono (2014). "The Realistics Learning Model With Character Education And PISA Assesment To Improve Mathematics Literacy". International Journal of Education and Research, 2(7): 361-372

Wardono, S B Waluya, Scolastika Mariani \& S Candra D (2016) Mathematics Literacy on Problem Based Learning with Indonesian Realistic Mathematics Education Approach Assisted ELearning Edmodo. In Journal of Physics 693(1)

Wardono \& S Mariani (2018), The analysis of mathematics literacy on PMRI learning with media schoology of junior high school students, Journal of Physics. 983

Widyastuti, N.S. (2014). Pengaruh Pendidikan Matematika Realistik Indonesia (PMRI) terhadap Pemahaman Konsep dan Berpikir Logis Siswa. Jurnal Prima Edukasiana, 2(2): 183-193

Wong. (2005). "Mathematical Literacy of Hong Kong's 15-Year-Old Students in PISA". EducationJournal, 31(2): 91-120 